GILA HEFER

Higher Studies Israel

\author{
THE USE OF CODE SWITCHING \\ AS A COMMUNICATIVE STRATEGY \\ BY THE LUBAVICHER EMISSARIES \\ WORKING WITH JEWISH AMERICAN STUDENTS: \\ THE INTERACTION BETWEEN LUBAVICHER EMISSARIES \\ AND THEIR AMERICAN STUDENTS
}

\begin{abstract}
Hefer Gila, The Use of Code Switching as a Communicative Strategy by the Lubavicher Emissaries Working with Jewish American Students: The Interaction Between Lubavicher Emissaries and their American Students [Zmiany kodu językowego jako strategia komunikacji wykorzystywana przez Emisariuszy Chabad-Lubawicz $\mathrm{w}$ pracy ze studentami amerykańskimi żydowskiego pochodzenia: interakcja pomiędzy Emisariuszami Chabad-Lubawicz i amerykańskimi studentami]. Studia Edukacyjne nr 37, 2015, Poznań 2015, pp. 349-361. Adam Mickiewicz University Press. ISBN 978-83-2322967-4. ISSN 1233-6688. DOI: 10.14746/se.2015.37.20
\end{abstract}

In this article there will be an endeavor to discuss the alternation of "Jewish English" to "standard", "regular" English in the form of code switching (CS), by Jewish Lubavitch emissaries in university campuses in the United States of America. I will examine what CS, a widely observed linguistic phenomenon, especially seen in multilingual and multicultural communities, is, and who the code switchers are. I will explore what interests motivate them to switch their code, how competent they are at switching, and the circumstances in which they are prone to switch their code. I will trace the idiosyncratic use of CS by this exclusive ethnic community as an increasing socio-pragmatic linguistic devise. It will also be observed as a minor psycho-linguistic need at various gatherings and classes, as an unconscious act of teaching a similar but foreign language to their audience (i.e. interlocutors). Thus, the discussion and findings of this study might expand familiarity with, and understanding of, the CS phenomenon.

Key words: Code-Switching, Intrasentential-intersentential CS, Bilingualism-Multilingualism, Lubavitch Emissaries

\title{
Code switching in Literature
}

The prevalent and simple linguistic definition of Code Switching (CS) is a language contact phenomenon in which two or more languages are used 
within the same discourse unit. ${ }^{1}$ In other words, Walters ${ }^{2}$ defines this phenomenon as a bilingual phenomenon, where a single speaker uses two languages in a sentence, across speaking turns, from topic to topic, setting to setting, listener to listener. In a conversational act there can appear "intrasentential" CS or "intersentential" CS. The directionality may also be switched from L1 to L2 and vice versa. It depends on the speaker's verbal competence and his/her lexical ability in both languages. Lexical gaps may cause the non-native speakers of a specific language to return to his/her mother tongue. Regev ${ }^{3}$ argues that "intrasentential" CS is more common than "intersentential" CS in both directions.

There has been a diversity of different CS theories that have a range of approaches to CS. In this paper I will present several theories in order to understand this phenomenon amongst the Lubavicher emissaries and the American students they interact with.

There are firstly the structural approaches, claiming that CS has some applicable universal predictive grammatical rules. Such modals will be outlined as Poplack's linear model ${ }^{4}$, Disciullo, Musyken, and Singh's generative model (1986), and the psycholinguistic model (1993).

Poplack's (1980) Linear order constraint model has two surface structure constraints: the Equivalent Constraint (EC) and the Free Morpheme Constraint (FMC). The EC states that codes will tend to be switched at points where the surface structures of the language map onto each other, and according to the FMC a switch may occur at any point in the discourse at which it is possible to make surface constraint cut and still retain a free morpheme. ${ }^{5}$ As a result, the CS is prohibited where the two languages differ in their surface structure.

The Generative models based on Chomsky's $(2000)^{6}$ Government and Binding generative grammar approach, propose that CS should be prohib-

\footnotetext{
${ }^{1}$ I. Regev, Socio Pragmatic and Psycholinguistic aspects of Code Switching in Bilingual Discourse, Ramat Gan 2003.

${ }^{2} \mathrm{~J}$. Walters, Bilingualism: The sociopragmatic - psycholinguistic interface, Mahwah, New York 2005.

${ }^{3}$ I. Regev, Socio Pragmatic and Psycholinguistic aspects.

${ }^{4}$ S. Poplack, Sometimes I"ll start a sentence in Spanish y termino en Espanol: toward a typology of code-switching, Linguistics, 1980, 18, p. 581-618.

${ }^{5}$ Ibidem, R. Raichlin, Codeswitching among Sequential Bilingual Children Structural, Psycholinguistic and Sociopragmatic Dimentions, Ramat Gan 2006.

${ }^{6}$ N. Chomsky, Inimalst Inquiries: The Framework, [in:] Step by Step: Essays in minimalist Syntax in Honor of Howard asnik, Eds. R. Martin, D. Michaels, J. Uriagereka, Cambridge Mass 2000, p. 89-155.
} 
ited within the maximal projection. ${ }^{7}$ Others, such as Belazi, Rubin and Toribio ${ }^{8}$, whose proposal was the Functional Head Constraint, claim that CS occurs between a functional element and its complement. The Competence model of Mahootia ${ }^{9}$, which is more general and MacSwan ${ }^{10}$ who adopted Chomsky's Minimalist Program, both have implications for CS.

The Psycholinguistic model is the Myers-Scotton's Matrix Language Frame (MLF) (1993) and the 4-M models account for intra-sentential CS. He claims that the intra-sentential CS is divided into two types: classic CS and composite CS. He concludes that in classic CS, only one of the participating languages is the source of the morphosyntactic structure of the bilingual clause, whereas the morphosyntactic structure consists of two languages in composite code switching.

Beside the structural approaches, there are additional pragmatic approaches to understanding CS motivations. The approach of Gumperz's CS functions ${ }^{11}$, claims that "CS signals contextual information equivalent to what in monolingual setting is conveyed through prosody or other syntactic or lexical processes. It generated the presuppositions in terms of which the content of what is said is decoded". He suggests three types of CS: situational CS, metaphorical CS, and conversational CS. These are used for: quotation, reiteration, interjection, message qualification, addressee specification and personification vs. objectification.

The Markedness model generated by Myers-Scotton 12 is that "speakers have a sense of markedness regarding available linguistic codes for any interaction, but choose their codes based on the persona and/or relation with others which they wish to have in place". ${ }^{13}$ She assesses that in multilingual communities exist right - and - obligations sets.

7 A.M. Disciullo, P. Musyken, R. Singh, Government and code-mixing, Journal of Linguistics, 1986, 22, p. 1-24.

${ }^{8}$ H. Belazi, E. Rubin, A.J. Toribio, Ode switching and $x$-bar theory: The Functional Head Constraint, Linguistic Inquiry, 1994, 25(2), p. 221-237.

9 S. Mahootian, A null theory of codeswitching, Phd thesis, Evanston IL 1993 and A competence model of cideswitching, [in:] Socioliguistic variation: Data, theory, and analysis, Selected papers from NWAVE 23 at Stanford University, Stanford CA 1996.

${ }^{10} \mathrm{~J}$. MacSwan, The architecture of the bilingual language faculty: evidence from intersentential code switching, Bilingualism: Language and Cognition, 2000, 3(1), p. 37-54 and Codeswitching and generative grammar: A critique of the MLF model and some remarks on "modified minimalism", Bilingualism: Language and Cognition, 2005, 8(1), p. 1-22.

11 J. Gumperz, Discourse Strategies, Cambridge 1982.

${ }_{12}$ C. Myers-Scotton, Social Motivations for Codeswitching: Evidence from Africa, Oxford 1993.

${ }^{13}$ C. Myers-Scotton, Duelling Languages: Grammatical structure in codeswitching, Oxford 1993, p. 75. 
Another model that attempts to account for CS is Walter's Sociopragmatic Pscholinguistic (SPPL) model. ${ }^{14}$ Contrary to the above mentioned approaches based on situational and external factors, Raichlin ${ }^{15}$ claims that the SPPL model integrates several domains: linguistic, psychological, sociological and pragmatic. Walters $(2005)^{16}$ argues that "...the major CS motivations may be either sociolinguistic or psycholinguistic". In addition, he claims that CS is "goal driven and motivated by identity as well as external, contextual factors" while "structural-psycholinguistic CS stems from individual linguistic and mental factors, in particular difficulties in finding words". 17 Therefore, It is inferred that "Sociopragmatic CS addresses how people relate to the real world whereas psycholinguistic CS deals with "'what is inside the head", that is, cognitive factors such as translation and paraphrasing". ${ }^{18}$ Rai$\operatorname{clin}^{19}$ concludes that the SPPL model assumes that "information about language choice is grounded in the social world, and language choices are possible at every stage of production". Altman ${ }^{20}$, who based on Walters' model, divided the motivations of CS into two general categories - sociopragmatic and psycholinguistic motivations. ${ }^{21}$

Altman $^{22}$ attributes CS to psychological motivations- such as retrieval problems, fluency effects and higher frequency of a word in one of the languages. Altman explains that retrieval problems derive from the fact that the speaker finds it difficult to access the word he needs (although he knows it) and fluency difficulties may occur when the speaker is concerned with smoothly continuing his utterance. In addition, Altman suggests that the act of CS is a result of linguistic influences such as lexicalization differences, or when the bilingual doesn't have an equivalent lexical item when he has to translate. Also, there may be no exact meaning of the word or expression he needs. This is called a lexical gap. Another reason motivating the bilingual to CS is phonologically based; when two words in the two languages have a similar phonology. Altman remarks that CS can be influenced by social reasons, such as to indicate a change in setting, role, listener or topic; ac2005.

14 J. Walters, Bilingualism: The sociopragmatic - psycholinguistic interface, Mahwah, New York

${ }^{15}$ R. Raichlin, Codeswitching among Sequential Bilingual Children Structural, Psycholinguistic and Sociopragmatic Dimentions, Ramat Gan 2006.

${ }^{16} \mathrm{~J}$. Walters, Bilingualism: The sociopragmatic - psycholinguistic interface.

17 Ibidem.

18 Ibidem.

${ }^{19}$ R. Raichlin, Codeswitching among Sequential Bilingual Children Structural.

${ }^{20}$ C. Altman, Codeswitching as an identity indicator in bilingual narratives. Telling stories: building Bridges among Language, Narrative, identity, interaction, society and culture, Washington DC 2008.

21 Walters J., Bilingualism: The sociopragmatic.

22 C. Altman, Codeswitching as an identity indicator in bilingual narratives. 
commodation to listener or to express affect. Moreover, pragmatic reasons may also motivate CS, such as focusing or showing emphasis, showing a contrast, and for narrowing or summarizing a point. In discourse, CS may be used when repeating a word or phrase, to quote from someone and to translate.

The Lubavitch emissaries' linguistic production is presumably a classic manifestation of linguistic anthropology of the relationship between the use of languages of any ethnic group and their identity. It probably has much to do with the use of traditional language not spoken anywhere but in the group, and how they use what is defined as "indexical" signs that create lexical meanings, on the fly so to speak, Kulic. ${ }^{23}$ In addition, Woolard ${ }^{24}$ in her overview of "code switching", or the systematic practice of alternating linguistic varieties within a conversation or even a single utterance, claims that this linguistic production reflects a dominate linguistic ideology. "It is the ideology that people should really be monoglot and efficiently targeted toward referential clarity rather than diverting themselves with the messiness of multiple varieties at play at a single time". ${ }^{25}$

The linguistic phenomenon of CS is vastly used as an unconscious linguistic devise throughout the communicative interactions of this specific ethnic group. Presenting the unique characteristics of this people, their origin, and the primary languages they speak, may augment understanding of their CS.

\section{The Code Switchers: The Spoken Languages and Population}

Linguistic CS occurs between Jewish Lubavitch English, and standard or regular English, by Jewish Lubavitch Brooklyn residents. Contrary to "standard" English (Fishman's definition, 1985) or "regular" English (Benor's definition, 2009), Jewish English is "a Jewish variety of English, with influences from Yiddish, textual Hebrew, and modern Hebrew", Benor. ${ }^{26}$ Gold ${ }^{27}$ and

${ }^{23}$ D. Kulic, Language Sift and Cultural Reproduction: Socialization, Self and Syncretism in Papua New Guinea Village, Cambridge 1992.

${ }^{24}$ K.A. Woolard, Codeswitching, [in:] Companion to Linguistic Anthropology, Ed. A Durani, Malden 2004, p. 73-94.

25 Ibidem.

26 S. Benor, Loan Words in the English of Modern Orthodox Jews: Yiddish or Hebrew? [in:] Proceedings of the Twenty-Fifth Annual Meeting of the Berkeley Linguistic Society,1999. Parasession on Loan Words Phenomena, Eds. S.S. Change et al., Berkeley 2000, p. 287-298.

${ }^{27}$ D. Gold, Jewish English, [in:] Readings in the Sociology of Jewish Languages, Ed. J.A. Fishman, Brill 1985, p. 280-298. 
Steimetz ${ }^{28}$ state that there is a great deal of variation according to region, generation, religiosity, and gender, but all varieties of English spoken by Jews can be discussed under the umbrella of Jewish English. Furthermore, Jewish Lubavitch English is yet another variable or version or perhaps may be considered as a sub- Jewish language due to its particular linguistic characteristics.

This article will deal with the phenomenon in which Lubavitch emissaries are forced to switch their language, when they go out to fulfill their Jewish spiritual mission outside of their familiar surroundings, interacting with Americans unfamiliar with their dialect. It is assumed that they lack basic linguistic knowledge in normative English since most of the Lubavitch youngsters of today are Jewish Lubavitch English speakers, who speak Yiddish as well. In other words, the majority of Chabad people are Yiddish and Jewish English bilinguals.

My initial hypothesis is that these people will encounter linguistic difficulties when they code switch and these linguistic gaps will be bridged in time based on the following variables: The emissary's personal linguistic competence, his linguistic flexibility in implementing CS appropriately, his previous exposure to the outer world, and finally his intellectual, emotional and social intelligence. The importance of the last variable stems from the fact that the social dynamics are affected by two strong factors which are interrelated, namely, content and form. The content is the message the emissary attempts to transfer to his listeners. This requires higher order thinking skills, emotional sensitivity, linguistic flexibility as well as knowledge of Judaic philosophy. Form is also a dominate factor and is determined by the emissary's ability to express himself correctly by using appropriate conversational linguistic syntactic and grammatical rules.

The origin of the Lubavitch emissaries is the Brooklyn enclaves of New York where they have been living since 1935. Like the other ultra- and modern -Orthodox Jews who live in Brooklyn, their speech acts are conducted in a mixture of Yiddish, Modern Hebrew, elements from ancient Jewish sources, and English. This mixture of languages, which has been developing in America since the previous century, is called "Jewish English" (their L1). Based on Lubavitch ideology, and upon the urging of their Lubavitch leader, many newly married young couples of this movement move out of Brooklyn to settle in non-traditional Jewish locations, often around university campuses, in order to influence and educate Jews whose knowledge of and con-

${ }^{28}$ S. Stienmetz, Yiddish and English: A Century of Yiddish in America, Tuscaloosa 1987. 
nection to Judaism is limited. Their goal is to expose these Jews to their religious roots.

At this stage, the first code switching (i.e. from Jewish English-L1 to regular English-L2) occurs as the emissary has to produce fluent and accurate English in order to communicate his ideas to potential believers. Whether the emissary is linguistically competent enough to produce appropriate discourse requirements, or whether he has linguistic gaps stemming from his lack of linguistic familiarity and insufficient practice of regular English, will be researched in depth. Whether his linguistic incompetence is unbridgeable, and consequently whether he fails in transferring his message, is another issue that will be dealt with in this research.

Gradually, vis a vis the readiness and spiritual progress of the newly inducted Jewish students, there occurs another partial, moderate and limited CS from regular English to Jewish English; i.e. from L2 backwards to L1. In this stage the "turn taking" has to be examined, since my assumption is that the emissary's language choice will be to switch to his L1, i.e., Jewish English, as quickly as the newly religious person acquires elementary Judaic notions. On the other hand, the student's linguistic preference will be his L1, which is regular English. Probably, later on in this lengthy process, CS will occur and be increasingly adopted by the potential person interested in Judaism (mekorav - a person who shows interest in learning about Judaism), depending on his or her spiritual growth or developing sense of cultural belonging. At the end of this spiritual journey, the mekorav will switch to full Jewish (Lubavitch) English.

It should be noted that this spiritual, intellectual and mainly linguistic CS dynamic (in relation to this study) repeatedly occurs with contemporary Lubavitch emissaries and their mekoravim everywhere in the USA. It seems that this cyclic process may be more sophisticated especially in the act of turn taking. At a Chabad gathering or at the Shabbat dinner table where there may be a large number of people, whose spiritual level and familiarity with Judaism varies from person to person, the emissary's speech act will be switched again and again, taking into consideration the variables of the guests' familiarity with the emissary's L1. Needless to say, the topics conveyed and discussed by the emissary are about Jewish notions, and consequently the emissary has to make a CS to "translate" these notions into regular English. Only at a much later stage may translation become unnecessary. Therefore, in order to please and influence the Chabad House guests, as well as his personal family members, the emissary has to jump from L1 to a partial L2 or to a complete L2, or to use the lexical access only in L1. 


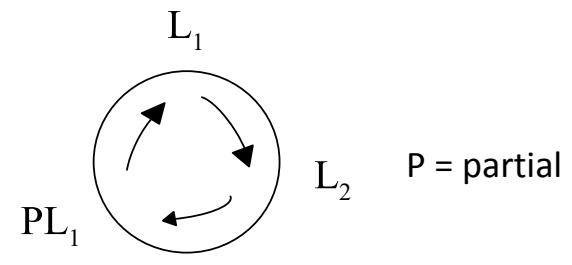

Fig. 1. Cyclic process of the emissary's CS

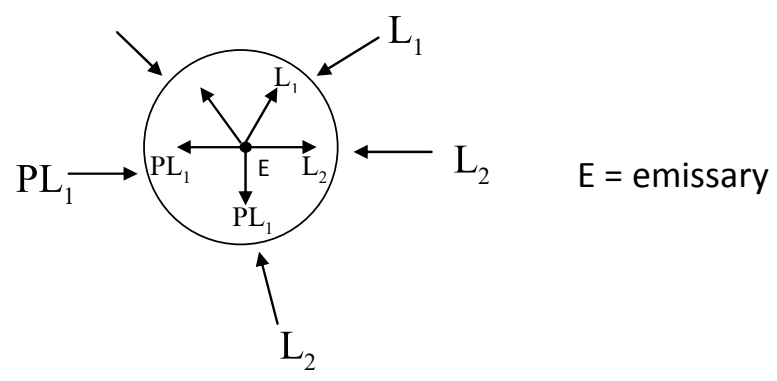

Fig. 2. Turn Taking act of the emissary

Being that, growing up, the Lubavitch emissaries have nary any exposure to regular English outside of their communities, and have no formal secular education, it seems surprising that they should interact successfully with secular Jews. However, I presume that at the end of this CS process they meet the linguistic level of Modern Orthodox society who do experience exposure to regular English as part of their education. Paradoxically, these very unworldly, linguistically ignorant emissaries will likely become successful Jewish English - regular English bilinguals, just like the more modern orthodox Jews. In other words, both, modern orthodox bilinguals and Lubavitch emissaries will successfully be able to code switch words and conduct a fluent and accurate conversation in the second language due to frequent use of the L2 (taken as an analogy from the research made by Heredia and Brown2000 about CS Spanish- English bilinguals).

\section{Multilingualism: \\ Jewish Language, Jewish English, Lubavitch Jewish English versus Regular English}

The Jews in New York nowadays characterize practically and historically their fellow Jews whose "home" language was different from the language spoken by their non-Jewish neighbors. This language is called Jewish Eng- 
lish. Uzzi Ornan ${ }^{29}$ defines it as "one that Jews speak only amongst themselves, and which is different from the one used outside their homes or neighborhoods". Therefore, today Jewish English can be seen as a variant of a Jewish language such as Ladino amongst Turkish and Spanish Jews and Yiddish amongst the Eastern European Jews.

Jewish English is the language developed in America among Jews throughout the previous and the current era. Benor ${ }^{30}$, Stimetz ${ }^{31}$ Fishman $^{32}$ who are the leading figures in this domain, remark that the difference between Jewish English and regular English can be as small as the addition of just a few Hebrew or Yiddish words (e.g. Hannukah, matzah ball, shlep), or it can be as large as multiple influences from Yiddish in syntax, lexicon, and phonology. The former is common among Jews with little or no religious practice, and the latter is used today mainly by Orthodox Jews. Orthodox Jewish English includes hundreds of loan words from Hebrew and Yiddish. Some loan words are semantically specialized, other features include quasichanting intonation contours, loan uses from Yiddish, frequent word -final / $t$ /-release, and Yiddish - influenced periphrastic constructions. Today we see the existence of Orthodox speech styles, especially the registers associated with the predominantly male learning institution, the yeshiva. Weiser ${ }^{33}$ calls this language "Yeshivish English", which is totally different from the regular English.

Concerning the Lubavitch Hasidim, they have their specific unique terms which are borrowed from Hebrew and Yiddish and stem from Chabad authentic sources, ideology and interests.

\section{A discussion of the use of CS throughout emissaries and students' interaction}

The initiative encounters of emissaries (the bilingual) with the American students (mostly the interlocutors, monolingual) takes place mainly at friendly gatherings or in classroom settings. The interaction conducted by both generates opportunities of conversational acts accompanied by massive

${ }^{29}$ U. Ornan, Jewish Language, [in:] The Sociology of Jewish Languages, Ed. J.A. Fishman, Brill 1985, p. 19-35.

30 S. Benor, Loan Words in the English of Modern Orthodox Jews, p. 287-298.

${ }^{31} \mathrm{~S}$. Stienmetz, Yiddish and English.

32 J.A. Fishman, The Sociology of Jewish Languages from a General Sociolinguistic. Point of View, [in:] Reading in the Sociology of Jewish Languages, Ed. J.A. Fishman, Brill 1985, p. 3-21.

${ }^{33}$ C. Weiser, Frumspeak: The First Dictionary of Yeshivish, New York 1995. 
use of CS. There is a linguistic gap on both sides. Therefore, in order to communicate appropriately, the emissaries are challenged to code switch from Jewish English into normative Standard English. The American students, in turn, with time, seek to acquire Jewish English as a means of acquiring the Jewish content which is ultimately the goal of their encounters.

The strategies applied by the emissaries, as well as the less active participants of this discourse, the Jewish American students, and their motivations, based on Walters' ${ }^{134}$ model, are suggested and discussed below:

- Normative English as a general framing- The emissaries use a standard, normative English as a frame, including, lexis, grammar, syntax and, phonology, when they converse about universal themes. This fact probably proves that they are familiar with the language spoken in U.S.A. Regarding the students, who are lacking basic knowledge in Judaism, this fact shows that when there is a minor limited use of intrasentential CS in a conversational act, it does not ruin the understanding of the whole sentence in class. However, when there is a massive use of intersentential CS or even a complicated intrasentencial CS which is a mixture of loan words from Yiddish, Aramaic, modern and ancient theological Hebrew sources within a sentence, it prevents the understanding of context or discourse. Therefore, the former use of CS is common among Jews with little or no religious practice, and the latter is used today mainly by Orthodox Jews. ${ }^{35}$ The emissaries are UltraOrthodox Jews whose practice is on a higher level.

- Gender differences- throughout various discourses and classes it was quiet clear that the emissaries significantly decrease CS when they converse with women only, and the amount of CS dramatically rises when they teach Jewish concepts to men only. The motivation is apparent. Women have less of an obligation than men do, to study Jewish texts and therefore need not have as much exposure to theological sources written in Aramaic and ancient Hebrew. Consequently, the emissaries do not find it necessary to switch the code for them, and speak more normative English.

- The use of Hebrew "loans"36 with a Hebrew accent for formal religious concepts, prayers and "codes". The following sentences are examples, quoted by the emissary from "Halachic" book (the book of codes):

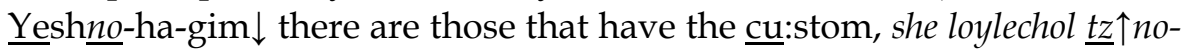

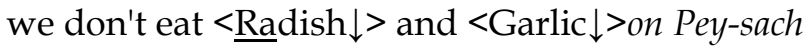

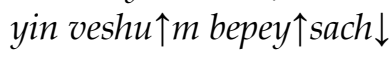

${ }^{34} \mathrm{~J}$. Walters, Bilingualism: The sociopragmatic.

35 C. Weiser, Frumspeak: The First Dictionary of Yeshivish.

${ }^{36}$ S. Benor, Loan Words in the English of Modern Orthodox Jews, p. 287-298; J.A. Fishman, The Sociology of Jewish Languages from a General Sociolinguistic, p. 3-21. 
In this sentence there is an intersentential CS and the direction is from the unknown lexical items to the known lexical items. In this example, the emissary unconsciously chooses to perform and teach the students new concepts in a complete utterance and later to translate the whole sentence. Sociopragmatic motivations led the emissary to apply such strategy. As Altman ${ }^{37}$ infers for discourse purposes, the CS occurred for translating, repeating a word or phrase and for quoting from someone; in this case from a theological source.

It should be remarked that the emissary hasn't here translated each and every word, such as "Pey-sach". It seems that this word switched to a concept in Hebrew that has been taught already and translation is no longer necessary. The repetitive act applied by the emissary in order to teach a new word/concept / expression is found to be effective since the student can utter and understand the word afterwards, on his own.

No psycholinguistic motivations were found in this sentence, since the emissary is not dealing with difficulties such as word retrieval, fluency or seeking equivalent lexical items. ${ }^{38}$

- The use of Aramaic for religious concepts.

- The use of Yiddish for folkish purposes.

There has been found high frequency of intersentential CS to Yiddish when dealing with folkish urposes. For instance: Of no $\uparrow t$ drinkin e:h-(of not drinking...)

Once more it was a sociopragmatic motivations for retrieving a verb in yiddish instead of normative English. According to Altman ${ }^{39}$ the CS occurs for focusing or showing emphasis, or to express affect.

- Deviations from the regular English frame - the emissaries may deviate from the syntactic and grammatical rules of English and will switch to Hebrew 's rules, for instance, "He read Seforim rabim"(he read many books). The subject and the verb were used according to the English rules but then the adjective had to appear before the noun, the object according to the English syntax. Here the emissary deviated from the English frame and adopted the Hebrew rules when locating the adjective after the noun rather than before. Here it seems that psycholingustic CS motivated the emissary to make such an utterance since he met word retrieval and fluency difficulties, as Altman claims. ${ }^{40}$

\footnotetext{
${ }^{37}$ C. Altman, Codeswitching as an identity indicator in bilingual narratives.

38 Ibidem.

${ }^{39}$ Ibidem.

${ }^{40}$ Ibidem.
} 
- Creative combinations of mixing English syntactic rules with non English word. For instance;" Yiddendom". The root is in yiddish and the suffix is as used in English.

\section{Conclusion}

It is my aspiration that discussion of the alternation of "Jewish English" to "standard" - "regular" English in the form of code switching by Jewish Lubavitch emissaries in university campuses in the United States of America, will shed light on the CS phenomena at large. Examining the nature of CS, what motivates it and the strategies used by the Lubavitch emissaries to incorporate it in their speech, will enhance our understanding of this behavior.

\section{BIBLIOGRAPHY}

Altman C., Codeswitching as an identity indicator in bilingual narratives. Telling stories: building Bridges among Language, Narrative, identity, interaction, society and culture. Georgetown University Roundtable (GURT) on Language and Linguistics, Washington DC 2008.

Belazi H., Rubin E., Toribio A.J., Ode switching and $x$-bar theory: The Functional Head Constraint, Linguistic Inquiry, 1994, 25(2).

Benor S., Loan Words in the English of Modern Orthodox Jews: Yiddish or Hebrew? [in:] Proceedings of the Twenty-Fifth Annual Meeting of the Berkeley Linguistic Society,1999. Parasession on Loan Words Phenomena, Eds. S.S. Change et al., Berkeley Linguistic Society, Berkeley 2000.

Benor S.B., Do American Jews Speak a 'Jewish English'? A Model of Jewish Linguistic Distinctiveness, Jewish Quarterly Review, 2009, 99(2).

Benor S.B., 2011 Jewish English.org/Jewish-English.Html.

Benor S.B., Cohen S.M., Survey of American Jewish Language and Identity, Hebrew Union College-Jewish Institute of Religion, Hebrew 2009.

Chomsky N., Inimalst Inquiries: The Framework, [in:] Step by Step: Essays in minimalist Syntax in Honor of Howard asnik, Eds. R. Martin, D. Michaels, J. Uriagereka, MIT Press, Cambridge Mass 2000.

Disciullo A.M., Musyken P., Singh R., Government and code-mixing, Journal of Linguistics, 1986, 22.

Fishman J.A., The Sociology of Jewish Languages from a General Sociolinguistic. Point of View, [in:] Reading in the Sociology of Jewish Languages, Ed. J.A. Fishman, Leiden, Brill 1985.

Gold D., Jewish English, [in:] Readings in the Sociology of Jewish Languages, Ed. J.A. Fishman, Leiden, Brill 1985.

Gumperz J., Discourse Strategies, Cambridge University Press, Cambridge 1982.

Heilman S., People of the Book, University of Chicago Press, Chicago 1983. 
Heredia R.R., Brown J.M., Code Switching. In the Encyclopedia of Linguistics, Fitzroy Dearborn Publishers, Chicago 2011, http:/ / www.taminu.edu/ rheredia/switch.htm.

Jochnowitz G., Bilinualism and Dialects Mixture among Lubavitcher Hasidic Children, American Speech, 1968, 43(3), p. 188-200. Reprintedin in J.A. Fishman 9 Ed., Never Say Die: A thousand Years of Yiddish in Jewish Life and Letters, Mouton, The Hague 1981.

Kulic D., Language Sift and Cultural Reproduction: Socialization, Self and Syncretism in Papua New Guinea Village, Cambridge University Press, Cambridge 1992.

MacSwan J., The architecture of the bilingual language faculty: evidence from intersentential code switching, Bilingualism: Language and Cognition, 2000, 3(1).

MacSwan J., Codeswitching and generative grammar: A critique of the MLF model and some remarks on "modified minimalism", Bilingualism: Language and Cognition, 2005, 8(1).

Mahootian S., A null theory of codeswitching, Phd thesis, Northwestern University, Evanston IL 1993.

Mahootian S., A competence model of cideswitching, [in:] Socioliguistic variation: Data, theory, and analysis, Selected papers from NWAVE 23 at Stanford University, CSLI Publications, Stanford CA 1996.

Myers-Scotton C., Duelling Languages: Grammatical structure in codeswitching, Oxford University Press, Oxford 1993.

Myers-Scotton C., Social Motivations for Codeswitching: Evidence from Africa, Clarendon Press, Oxford 1993.

Ornan U., Jewish Language, [in:] The Sociology of Jewish Languages, Ed. J.A. Fishman, Leiden, Brill 1985.

Poplack S., Sometimes I"ll start a sentence in Spanish y termino en Espanol: toward a typology of code-switching, Linguistics, 1980, 18.

Raichlin R., Codeswitching among Sequential Bilingual Children Structural, Psycholinguistic and Sociopragmatic Dimentions, Bar Ilan University, Ramat Gan 2006.

Regev I., Socio Pragmatic and Psycholinguistic aspects of Code Switching in Bilingual Discourse, Bar Ilan University, Ramat Gan 2003.

Stienmetz S., Yiddish and English: A Century of Yiddish in America, University of Alabama Press, Tuscaloosa 1987.

Walters J., Bilingualism: The sociopragmatic - psycholinguistic interface, Lawrence Erlbaum Assiciates, Mahwah, New York 2005.

Weinreich M., History of the Yiddish Language, University of Chicago Press, Chicago 1980.

Weiser C., Frumspeak: The First Dictionary of Yeshivish, Jason Aronson, Northvale, New York 1995.

Woolard K.A., Codeswitching, [in:] Companion to Linguistic Anthropology, Ed. A Durani, Blackwell, Malden 2004. 